\title{
ESTABLISHING CUT-OFFS FOR NON-INVASIVE LIVER TESTS TO DETECT CIRRHOSIS AT A HIGH SENSITIVITY
}

\author{
Andrejs Ernests Zirnis ${ }^{1, \#}$, Zane Straume ${ }^{1,2}$, Raisa Bērziṇa ${ }^{1}$, Justīne Māliṇa-Bambīte ${ }^{1}$, \\ Aleksejs Derovs $^{1,2}$, and Inese Zeltina ${ }^{1,2}$ \\ ${ }^{1}$ Rīga Stradinš̌ University, 16 Dzirciema Str., Rīga, LV-1007, LATVIA \\ ${ }^{2}$ Rìga East Clinical University Hospital, 2 Hipokrāta Str., Rīga, LV-1038, LATVIA \\ Corresponding author, andrejs.zirnis95@gmail.com
}

Communicated by Aivars Pētersons

\begin{abstract}
Liver cirrhosis is the end stage of chronic liver diseases. The current gold standard for diagnosing this condition, liver biopsy, has too many drawbacks, and research for better alternatives is ongoing. One major diagnostic arsenal includes various serological composition scores or so-called formulas. They are constantly being validated for development of new formulas. In our retrospective study of 215 patients case files who had confirmed cirrhosis of various etiologies, we examined the sensitivity and set new cut-offs for five of the most well-documented formulas. Data was obtained from the Riga East University Hospital from 2012 to 2017 and analysed using SPSS V.22.00. In our study we found that FIB-4 at cut-off $>1.45$ had over $95 \%$ sensitivity for excluding advanced fibrosis regardless of cirrhosis etiology. None of evaluated formulas had high sensitivity for detecting cirrhosis of alcohol etiology. For the viral hepatitis $C$ genesis group, the best choice was deRitis index with almost $90 \%$ sensitivity. FIB-4 at cut-off $>2.75$ was the best choice for the combined alcohol and viral hepatitis C group; BONACINI at score 8+ and FIB-4 at $>3.25$ were the most sensitive in the main group containing all patients irrespective of cirrhosis etiology.
\end{abstract}

Key words: diagnosing liver cirrhosis, serological markers, liver biopsy alternatives, FIB-4 and deRitis.

\section{INTRODUCTION}

With more than 500 different functions, liver can truly be considered as being one of the most diverse specialists in human body. It also possesses remarkable regeneration capabilities: even when up to $70 \%$ of the organ has been damaged or removed, it can regain its previous size and function (Minuk, 2003). However, just as there are many functions for liver, there are many factors and diseases that damage it. Usually onset of a chronic liver disease is very insidious, and the damage rarely manifests as clinical symptoms until it has accumulated to the point when liver cannot perform its functions or regenerate properly anymore. At this point, our options to help patients become very limited, so the main focus is on diagnosing chronical liver injury as early as possible.

The classical pathway of liver damage can be described in four steps: injury leads to liver inflammation (hepatitis), followed by fibrosis, cirrhosis and further by total decompensation of liver functions.
Histologically, in liver fibrosis is associated with destruction of hepatocytes, proliferation of myofibroblasts with excess deposition of extracellular matrix (ECM) and disappearance of normal hepatic microstructure (Friedman, 2008). Progressive histological stages are defined in the fibrosis process leading to the development of cirrhosis. One of the most widely used histological staging systems, METAVIR, distinguishes stage F0 representing lack of fibrosis; stage F1, portal fibrosis; stage F2, periportal fibrosis; stage F3, bridging fibrosis; and, finally, stage F4 representing cirrhosis (Poynard et al., 1996).

The end stage of fibrosis is cirrhosis. In this phase, the excess scar tissue has formed completely isolated small islands of hepatocytes, which have impaired blood supply. It is a chronic progressive clinical condition, leading to liver cell failure and portal hypertension, which in turn creates a micro-environment that favours the onset of hepatocellular carcinoma (Crawford, 2002). Clinically, liver cirrhosis can be divided into two stages - compensated and decompensated (Garcia et al., 2010). 
Decompensation is the final phase in the cirrhosis pathway, when liver permanently loses its functions; patients start to manifest well-known signs of insufficient detoxification, portal hypertension, and renal and pulmonary failure (Grünhage and Lammer, 2018). Estimated lifespan expectancy drops from 12 years in case of compensated cirrhosis to two years in decompensated cirrhosis (D'Amico et al., 2006; Gines et al., 1987). As of now, liver transplantation is the only treatment option when the decompensated cirrhosis stage is attained, but only few of the patients will be lucky enough to receive it. By establishing cirrhosis diagnosis early, it is possible to slow down the cirrhosis process and postpone cirrhosis decompensation while maintaining reasonably high quality of life.

As changes observed in liver are of a morphological nature, the gold diagnostic standard for detecting and staging for fibrosis still remains liver biopsy. While it has been used for decades, this method is far from being perfect; even when the possible complications of biopsy are excluded, other drawbacks remain. The histological results heavily depend on taking the tissue samples correctly - they must be at least 2 centimetres in length with at least 11 portal fields visible, which is not always possible. The samples taken represent only around 1/50 000 of total liver mass (Bedossa et al., 2003; Cholongitas et al., 2006). If we want to follow the natural course of fibrosis or evaluate the effectiveness of therapeutic agents, biopsies need to be repeated.

And even when the samples are taken correctly, interobserver variability between pathologists reaches as high as $20 \%$ (Regev et al., 2002).

Common complications of the procedure range from intraperitoneal haemorrhage, haemobilia, haemothorax (Machado et al., 2017) to acute hypotension and even vasovagal syncope (Kose et al., 2015). Patients with hepatocellular carcinoma are at risk of disseminating the malignant tissue during the procedure (Tchatalbachev et al., 2015). These problems have persuaded many researchers to study and develop alternative diagnostic tools.

Existing non-invasive liver fibrosis diagnostic methods can be divided into image-based examinations and various serological tests.

The majority of image-based diagnostic tools are ultrasound-based liver examination methods. The readouts of these measurements are either $\mathrm{kPa}$ or $\mathrm{m} / \mathrm{s}$, or both. One of them - transient elastography (FibroScan) - has been commercially available since 2005 and has become widely available, whereas the other technologies have been developed recently (Grünhage and Lammert, 2018). A more expensive alternative is magnetic resonance elastography (MRE). While it is more sensitive in diagnosing early stages of liver cirrhosis when compared to ultrasound-based methods (Huwart et al., 2008) its use is limited by its high price and the need of magnetic resonance equipment (Sande et al., 2017).
The second major group of non-invasive markers consists of various serological markers and their combinations or so-called formulas. They offer a cost-effective alternative to liver biopsy, are less invasive and theoretically without complications. Because of these features, they can be performed repeatedly and used in monitoring the fibrotic process dynamically, for instance, to follow up the efficacy of an antiviral therapy in the regression of fibrosis (Soresi et al., 2014). Based on parameters being used, formulas can also be further divided into ones that utilise direct markers and ones that consist of indirect markers. Direct serological biomarkers reflect the changes in the ECM structure, including markers of ECM turnover, fibrogenesis, and fibrolysis. Indirect serological biomarkers are related to liver damage and/or decline in liver function, which are associated with the development of fibrosis and cirrhosis (Lurie et al., 2015).

The majority of these formulas have been created and proven in only specific patient groups, mainly to detect fibrosis in patients with viral hepatitis C. Even the most studied commercially patented tests - FibroTest and FibroMeter - have been officially validated only for steatohepatitis, and alcohol and viral genesis fibrosis (Jenny Yeuk et al., 2017). This means that presently there is no universally agreed upon formula for detecting liver fibrosis for all chronic liver conditions, since different chronic liver diseases are characterised by distinct patterns of fibrosis deposition (Pinzani et al., 2005). While some of these formulas consist only of biomarkers that can be found in any standard blood or serum test (i.e. ALT, AST, platelets), others require more specific markers that are not routinely taken, such as hyaluronan (Orasan et al., 2016) and laminin (Mak KM et al., 2013). Obvious advantages of these are their availability and low to no-cost, but the main disadvantage lies in lesser sensitivity and organ specificity. The aim of our study was to evaluate how different non-commercial formulas can detect existing liver cirrhosis of various etiologies, observe at which theoretical cut-off values they could have $95 \%$ sensitivity and determine if these values can be used in clinical practice. In the retrospective study, we reviewed medical files of 215 patients with confirmed liver cirrhosis of various etiologies. All of the formulas we examined did not need any specific markers and could easily be used by any clinician in time of need.

\section{MATERIALS AND METHODS}

Patients. This retrospective study involved case files of 215 patients who were hospitalised in Rìga East University Hospital from 2012 to 2017. Patient data was obtained with the approval of the Rìga East Clinical University Hospital Ethical Committee. All of the patients had previously confirmed cirrhosis and were over 18 years of age. From their case files we obtained data on the necessary biomarkers and parameters: Alanine aminotransferase - ALT (units per liter, U/l), Aspartate aminotransferase - AST (U/l), platelets PLT $\left(10^{9} / 1\right)$, age (years), and International Normalized Ratio (seconds). We used laboratory tests taken in day one in 
order to minimise the possible effect after received treatment. After obtaining these data, the patients were further divided into subgroups based on cirrhosis etiology. In total we had five subgroups:

- Patients with cirrhosis, alcohol genesis $(n=107.50 \%)$.

- Patients with cirrhosis, viral hepatitis C genesis (VHC) $(\mathrm{n}=69 ; 32 \%)$.

- Patients with cirrhosis, primary biliary cholangitis (PBC) genesis $(n=7 ; 3 \%)$.

- Patients with cirrhosis, viral hepatitis B genesis (VHB) $(\mathrm{n}=4 ; 2 \%)$.

- Patients with combined alcohol and VHC genesis cirrhosis $(n=28 ; 13 \%)$.

Due to small sample sizes for VHB and primary biliary cholangitis group, we used only the alcohol, VHC and combined VHC and alcohol groups; PBC and VHB groups were added to the main group (it contained patients from all of the cirrhosis etiologies).

Formulas. We opted to use only those formulas that did not need specific markers and would be universally available for any healthcare specialist at no additional cost. These were: FIB-4, APRI, deRitis index, POHL score, and BONACINI index (Table 1).

The aim was to evaluate the ability of these formulas to detect cirrhosis of various etiologies. Firstly, we used the cutoffs that we were able to find in literature. Since we knew that all our patients had cirrhosis, anyone over the specified cut-off would be considered as a detected case.
Secondly, we set our own cut-offs — values at which we could detect more than $95 \%$ of cases. Further, a literature review for comparison of our results was made.

Statistics. Statistical analysis was done using SPSS V.22.00. Absolute frequencies and percentages were used to describe qualitative variables. Quantitative variables were described using range, mean and standard deviation (SD).

\section{RESULTS}

Of the 215 patients, $125(58.1 \%)$ were male and $90(41.9 \%)$ were females. The mean age was 53.6 years $( \pm 12.36)$.

Table 1 shows sensitivity of formulas when cut-off values found in studies by different authors were used. The most sensitive formula in all subgroups was FIB-4 at cut-off 1.45 with more than $95 \%$ sensitivity in all subgroups. It still retained its first place, when the cut-off was increased to 3.25 (higher cut-off generally means higher specificity). In the viral hepatitis $\mathrm{C}$ subgroup, the deRitis index also showed high sensitivity (88.9\%). In the combined VHC and alcohol genesis subgroup, all of the formulas showed sensitivity of over $70 \%$. In the group combining all five cirrhosis etiologies, apart from FIB-4, only the BONACINI score had sensitivity $(63.6 \%)$ over $60 \%$.

Table 2 shows our proposed cut-offs, that, according to our study, could detect at about $95 \%$ of cirrhosis cases. In the alcohol subgroup, the cut-off for BONACINI index should be 5 points, for FIB-4 1.63 and for APRI 0.32. In viral hepatitis $\mathrm{C}$ subgroup, the DeRitis index should be set at 0.8 cut-off, BONACINI at 4 points, FIB-4 at 1.48 and APRI at 0.32 . To increase the sensitivity to $95 \%$, in the combined alcohol and viral hepatitis $\mathrm{C}$ subgroup, cut-offs for BONAC-

Table 1. Formulas used in our study

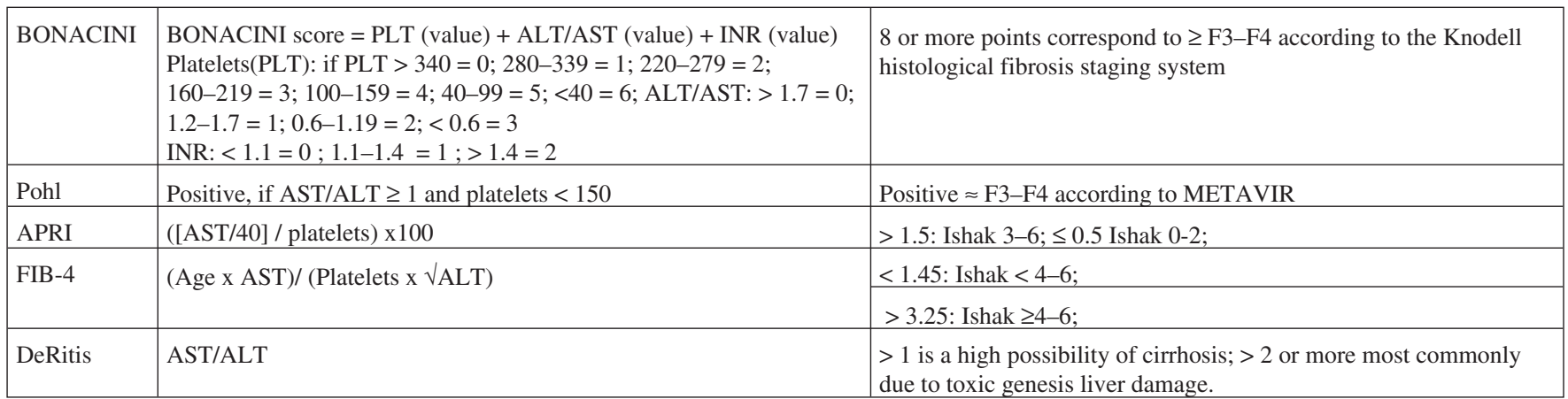

Table 2. Sensitivity of formulas in our study when cut-offs found in literature were used.

\begin{tabular}{|c|c|c|c|c|}
\hline & Alcohol subgroup & Viral hepatitis C subgroup & $\begin{array}{c}\text { Combined toxic and viral } \\
\text { hepatitis } \mathrm{C} \text { subgroup }\end{array}$ & $\begin{array}{c}\text { All } 5 \text { cirrhosis etiologies } \\
\text { combined group }\end{array}$ \\
\hline POHL & $50 \%\left(\mathrm{n}^{*}=74\right)$ & $59.3 \%(\mathrm{n}=54)$ & $71.4 \%(\mathrm{n}=21)$ & $56.7 \%(\mathrm{n}=157)$ \\
\hline BONACINI 8+ & $59.1 \%(\mathrm{n}=66)$ & $67.3 \%(\mathrm{n}=49)$ & $75 \%(\mathrm{n}=20)$ & $63.6 \%(n=143)$ \\
\hline FIB-4 cutoff $>1.45$ & $97.3 \%(\mathrm{n}=74)$ & $96.3 \%(\mathrm{n}=54)$ & $95.2 \%(\mathrm{n}=21)$ & $96.8 \%(\mathrm{n}=157)$ \\
\hline FIB- 4 cutoff $>3.25$ & $59.5 \%(\mathrm{n}=74)$ & $74.1 \%(n=54)$ & $81 \%(\mathrm{n}=21)$ & $66.9 \%(\mathrm{n}=157)$ \\
\hline APRI & $37.8 \%(\mathrm{n}=74)$ & $57.4 \%(\mathrm{n}=54)$ & $71.4 \%(\mathrm{n}=21)$ & $49.7 \%(n=157)$ \\
\hline DeRitis & - & $88.9 \%(n=54)$ & - & \\
\hline
\end{tabular}




\begin{tabular}{|c|c|c|c|c|c|}
\hline & & Alcohol subgroup & $\begin{array}{l}\text { Viral hepatitis C sub- } \\
\text { group }\end{array}$ & $\begin{array}{c}\text { Combined toxic and viral } \\
\text { hepatitis C subgroup }\end{array}$ & $\begin{array}{c}\text { All } 5 \text { subgroups } \\
\text { combined }\end{array}$ \\
\hline & $\begin{array}{c}\text { Cut-offs established } \\
\text { in literature }\end{array}$ & Our proposed $(\sim 95 \%)$ & Our proposed $(\sim 95 \%)$ & Our proposed $(\sim 95 \%)$ & Our proposed $(\sim 95 \%)$ \\
\hline DeRitis & 1 & - & 0.8 & - & - \\
\hline BONACINI & 8 points & 5 points & 4 points & 3 points & 4 points \\
\hline FIB-4 & $1.29 ; 1.45$ and 3.25 & 1.63 & 1.48 & 2.75 & 1.63 \\
\hline APRI & 1 and 1.5 & 0.32 & 0.32 & 0.26 & 0.32 \\
\hline
\end{tabular}

INI and APRI should be even lower - 3 points for BONACINI and 0.26 for APRI. For FIB- 4 it could even be increased to 2.75. In the group combining all five cirrhosis subgroups, the cut-offs were 4 points for BONACINI, 1.63 for FIB-4 and 0.32 for APRI. Since the POHL formula does not use numbers as the final answer, but a simple yes/no threshold, a cut-off level was not calculated.

The highest sensitivity was obtained for the FIB-4 formula at cut-off of 1.45 . It also had the closest results to established ones in our study.

\section{DISCUSSION}

Various formulas for detecting liver fibrosis have been known for decades. Ever since the AST/ALT ratio 1 was proposed as a criteria for significant liver fibrosis in nonalcohol genesis liver diseases (Williams and Hoofnagle, 1988), more complex scores have been proposed and studied. While liver biopsy is still the golden standard in liver fibrosis staging, the last 20 years have shown how imperfect this method is. Now we may be witnessing the beginning of the end of the first phase for the development of noninvasive markers. Some of the early evidence accumulated suggests that these markers might be at least as good as liver biopsy. These novel experimental markers and imaging techniques could lead to a dramatic change in liver fibrosis diagnostics in the near future (Lurie et al., 2015). Currently, there are two main directions for the development of these scores. Researchers working in one direction are proposing various formulas that do not need expensive and complex tests to be performed beforehand, making the fruits of their labour universally accessible by all clinicians at no cost. Studies being done in the other direction are focused on finding specific biomarkers for liver fibrosis. These biomarkers, while requiring complicated and often quite expensive tests, already allow to diagnose liver fibrosis at much higher level of certainty and accuracy than the ones that are not liver specific (Forns et al., 2002).

The DeRitis index or AST/ALT was proposed by deRitis already in 1957 (deRitis et al, 1957). Despite the long time since its proposal, it can still be used in clinical practice and the majority of formulas that were developed after it utilise it as a large part in their equations. Most studies regarding it are for detecting both severe fibrosis and cirrhosis in patients with hepatitis B and C.
Aspartate transaminase can be found in mitochondria and hepatocyte cytoplasm, but alanine aminotransferase is located only in hepatocyte cytoplasm. Review of various studies has showed that the elevation of AST, rather than ALT, is predictive of fibrosis (Botros and Sikaris, 2013). A study done by Ustündag et al. proved that in chronic hepatitis C an elevated deRitis ratio is correlated with fibrosis instead of necro inflammatory activity (Ustündag et al., 2000). A cut-off of 1 has proven to be a good predictor of significant fibrosis. In patients with cirrhosis caused by chronic viral hepatitis B and C this index does not usually exceed 2 (Park et al., 2004; Sheth et al., 1998); results above 2 are most likely caused by excessive alcohol consumption or other acute liver damage.

Regarding its sensitivity and specificity: AST/ALT ratio $<1$ has a high negative predictability value (NPV) for excluding cirrhosis (Giannini et al., 1999). In another study with patients infected with viral hepatitis $\mathrm{C}$ patients, it was estimated that a ratio $\geq 1$ had $95.9 \%$ specificity and $73.7 \%$ positive predictive value (PPV) in distinguishing cirrhotic from non-cirrhotic patients, with a $46.7 \%$ sensitivity and $88.1 \%$ negative predictive value (Park et al., 2000).

According to literature, the deRitis index cannot be used in alcohol genesis cirrhosis, so we used the deRitis index only for the VHC group. In these patients it showed an $88.9 \%$ sensitivity at cut-off 1 in detecting cirrhosis. In order to reach $95 \%$ sensitivity, the cut-off should be lowered to 0.8 . As its main strength for detecting cirrhosis in viral hepatitis $\mathrm{B}$ and $\mathrm{C}$ lies in its high specificity, we do not recommend using the cut-off 0.8 since even at cut-off 1 it still had excellent cirrhosis detection sensitivity.

APRI. The APRI formula was developed to amplify the effects of liver fibrosis on platelets and AST. In contrast to deRitis index, APRI uses two different cut-off values; $<0.5$ is used to exclude and $>1.5$ to predict significant fibrosis.

It was derived by Wai et al. (2003) and initially tested in a cohort of 270 hepatitis $\mathrm{C}$ patients. The authors reported NPV of excluding significant fibrosis of $86 \%$ and PPV of $88 \%$ when cut-off of above 1.5 was used. It was estimated that up to $50 \%$ of liver biopsies could be avoided if their formula was used (Wai et al., 2003). Subsequent studies by other authors were not able to reach such impressive results. In a meta-analysis of 22 studies done by Shaheen and Myers, APRI had $81 \%$ sensitivity and $50 \%$ specificity at 0.5 cut-off in diagnosing significant fibrosis, which translated 
to estimated PPV of $59 \%$ and NPV of $75 \%$. At cut-off of 1.5 , it had a specificity of $91 \%$, but sensitivity of only $35 \%$. For excluding cirrhosis, a cut-off of 1.0 was $76 \%$ sensitive and $71 \%$ specific, with estimated PPV of $50 \%$ and the NPV of $91 \%$ (Shaheen and Myers, 2007). Much weaker results were obtained in alcoholic patients co-infected with hepatitis C (Lieber et al., 2006).

In our study we tested APRI at cut-off 1.5. It had the highest sensitivity in the alcohol and VHC subgroup with $71.4 \%$. In the VHC subgroup, for which it was initially developed, the sensitivity was lower than we found in scientific literature - only $57.4 \%$. It also had the lowest sensitivity of all five formulas in the main group combining all five subgroups $(49.7 \%)$ and in the alcohol-only subgroup $(37.8 \%)$. In order to increase detected cases to $95 \%$, we would need to decrease the cut-off below 0.32 in all subgroups, which would make this formula too non-specific to be used clinically.

FIB-4 index. This index initially was developed for $\mathrm{HIV} / \mathrm{HCV}$ co-infected patients in the APRICOT study for separating between significant and less significant levels of fibrosis. According to this study, FIB-4 excludes advanced fibrosis with NPV of $89 \%$. Researchers also established two cut-offs: $<1.45$ and $>3.25$. When a cut-off of $<1.45$ was used, an NPV of $90 \%$ with sensitivity of $70 \%$ for excluding stage 4-6 fibrosis was obtained. Above cut-off 3.25, FIB-4 had a PPV of $65 \%$ combined with $97 \%$ specificity. They also estimated that up to $71 \%$ of liver biopsies could be avoided if these cut-offs were used (Sterling et al., 2006). In another study, Vallet-Pichard et al. validated these results in a large cohort of $847 \mathrm{HCV}$ mono-infected patients. According to their results, a cut-off below 1.45 had a $95 \%$ chance to rule out extensive fibrosis and a score above 3.25 had a positive predictability value of $82 \%$ (Vallet-Pichard et al., 2007).

Both FIB-4 and APRI have been recommended by World Health Organisation (WHO) guidelines to determine the stage of liver fibrosis in resource limited countries (Anonymous, 2014).

In our study, we evaluated both cut-offs for FIB-4: $<1.45$ and $>3.25$. A cut-off of 1.45 is recommended to exclude significant fibrosis; in our case more than $95 \%$ of all cases in all of the groups had a higher value, meaning that only less than $5 \%$ of patients with cirrhosis would be classified as not having significant liver fibrosis. These results are consistent with the previously mentioned studies. A cut-off of 3.25 can be used to diagnose cirrhosis; at this cut-off FIB-4 still had a high sensitivity in the viral hepatitis $\mathrm{C}$ subgroup and combined VHC and alcohol subgroup: $74.1 \%$ and $81 \%$, respectively, but only $59.5 \%$ in the alcohol and $66.9 \%$ in the main group.

The cut-offs that we would propose are very close to the ones recommended in literature, except for the combined VHC and alcohol genesis subgroup where it was 2.75. Most likely, this discrepancy can be explained by the smaller sample size $(n=21)$ for this group.

Bonacini index (cirrhosis discriminant score). This index combines the ALT/AST ratio with the platelet count and INR into a discriminant function with possible total values between zero and 11; higher values increase the likelihood of cirrhosis. It was developed by Bonacini et al. (1997) to detect advanced fibrosis. According to their study, it had positive correlation with histological scores and $98 \%$ specificity, but only $46 \%$ sensitivity when a threshold above 7 was used (Bonacini et al., 1997). In a recent study by Kell et al. (2018) in HCV mono-infected patients, a Bonacini score $<7$ had a negative prediction value of $88 \%$.

In our study, we used a cut-off of 8 and above. The sensitivity of it was the highest in the combined alcohol and VHC subgroup (75\%), followed by the VHC subgroup (67.3\%) and main group $(63.6 \%)$. For alcohol genesis cirrhosis the sensitivity was only $59.1 \%$, which was almost identical to FIB-4 at cut-off 3.25 .

A cut-off of 5 in the alcohol subgroup could detect about $95 \%$ of cases. A cut-off of 4 points could be used for VHC and main group and cut-off of 3 points in the combined $\mathrm{VHC}+$ alcohol group.

Pohl score. The Pohl score was developed for HCV mono-infected patients. It is a simple formula, with "yes/no" as the final answer. It is positive if AST/ALT ratio $>$ or $=1$ in combination with a platelet count of < $150000 / \mathrm{mm} 3$; according to the authors of this formula, it can identify patients with severe fibrosis or cirrhosis (stages 3 and 4) with a PPV of 93.1\%. Sensitivity, specificity, and NPV were estimated to be $41.2 \%, 99.1 \%$, and $85.0 \%$, respectively (Pohl et al., 2001). In other studies, the Pohl score has not been found to be a good index to determine the stage of fibrosis. In a study done by Azhar et al., sensitivity and specificity were $38.1 \%$ and $78.1 \%$, respectively, with AUC $=0.549$ for F4 stage fibrosis (Azhar et al., 2019).

In our study, the Pohl index had the highest sensitivity in the combined alcohol and VHC subgroup with $71.4 \%$ and the lowest in the alcohol subgroup - only 50\%. This is not surprising since the score uses only two parameters, which change the most during excessive alcohol consumption deRitis ratio and platelets. It had a very mediocre sensitivity in the viral hepatitis C subgroup $(59.3 \%)$ and the main group $(56.7 \%)$ as well.

\section{CONCLUSIONS}

As of now, we are better at excluding advanced fibrosis and cirrhosis with various biomarker formulas than detecting it. One of the take home messages at the European Association for the Study of the Liver (EASL) postgraduate course was that "simple and complex serum-based tests have $>90 \%$ predictive value for excluding cirrhosis, though are poorly predictive of cirrhosis" (Adams, 2015). We still have a long way to go, especially if we consider that each score and test 
must be validated for each of liver disease. However, we also hope that the results of our study will contribute its share for the development of better scores. According to our study, FIB-4 at cut-off $<1.45$ is the best for excluding advanced fibrosis, regardless of cirrhosis etiology, with overall less than $5 \%$ cases detected incorrectly. None of the formulas had high sensitivity in detecting cirrhosis caused by excessive use of alcohol. The best choice for this group could be BONACINI at 5 points (proposed value) or FIB-4 at cut-off 3.25. For the viral hepatitis $C$ subgroup, surprisingly, the best results in cirrhosis detection was shown by the deRitis ratio, detecting almost $90 \%$ of cirrhosis cases. For the combined viral hepatitis $\mathrm{C}$ and alcohol genesis cirrhosis subgroup, the choice could be FIB-4 at cut-off 2.75 (proposed value). For the main group, combining all patients irrespective of cirrhosis etiology, the best choice could be Bonacini at cut-off above 8 or FIB-4 at cut-off > 3.25 .

\section{REFERENCES}

Adams, L. A. (2015). Non invasive diagnosis of fibrosis in NAFLD, How reliable is it? In: The International Liver Congress. EASL Postgraduate Course: Metabolic Liver Disease, Vienna, 22--23 April 2015. Vienna, pp. 24-25.

Anonymous (2014). Guidelines for the Screening, Care and Treatment of Persons with Hepatitis C Infection. World Health Organization, Geneva. $56 \mathrm{pp}$.

Hussain, A., Gul, M. A., Khalid, M. U. (2019). Validation of novel fibrosis index (NFI) for assessment of liver fibrosis: Comparison with transient elastography (FibroScan). Brit. Med. J. Open Gastroenterol., 6 (1), e000316.

Bedossa, P., Dargere, D., Paradis, V. (2003). Sampling variability of liver fibrosis in chronic hepatitis C. Hepatology, 38, 1449-1457.

Bonacini, M., Hadi, G., Govindarajan, S., Lindsay, K. L. (1997). Utility of a discriminant score for diagnosing advanced fibrosis or cirrhosis in patients with chronic hepatitis C virus infection. Amer. J. Gastroenterol., 92 (8), 1302-1304.

Botros, M., Sikaris, K. A. (2013). The De Ritis ratio: The test of time. Clin. Biochem. Rev., 34 (3), 117-130.

Cholongitas, E., Senzolo, M., Standish, R., Marelli, L., Quaglia, A., Patch, D., Dhillon, A. P., Burroughs, A. K. (2006). A systematic review of the quality of liver biopsy specimens. Amer. J. Clin. Pathol., 125, 710-721.

Crawford, J. M. (2002). Liver cirrhosis. In: MacSween, R. N. M., Burt, A. D., Portmann, B. C. (eds.). Pathology of the Liver. $4^{\text {th }}$ ed. Churchill Livingstone, London, pp. 575-619.

D'Amico, G., Garcia-Tsao, G., Pagliaro, L. (2006). Natural history and prognostic indicators of survival in cirrhosis: A systematic review of 118 studies. J. Hepatol., 44, 217-231.

De Ritis, F., Coltorti, M., Giusti, G. (1957). An enzymic test for the diagnosis of viral hepatitis: The transaminase serum activities. Clin. Chim. Acta, 2 (1), 70-74.

Forns, X., Ampurdančs, S., Llovet, J. M., Aponte, J., Quintó, L., MartínezBauer, E., Bruguera, M., Sánchez-Tapias, J. M., Rodés, J. (2002). Identification of chronic hepatitis $\mathrm{C}$ patients without hepatic fibrosis by a simple predictive model. Hepatology, 36, 986-992.

Grünhage, F., Lammert, F. (2018). Chapter 19. Assesement of hepatic fibrosis and steatosis. In: Hepatology - a Clinical Textbook. $9^{\text {th }}$ edn. Mauss, Berg, Rockstroh, Sarazzin, Wedemeyer.

Friedman, S. L. (2008). Hepatic stellate cells: Protean, multifunctional, and enigmatic cells of the liver. Physiol. Rev., 88, 125-172.
Garcia-Tsao, G., Friedman, S., Iredale, J., Pinzani, M. (2010). Now there are many (stages) where before there was one: In search of a pathophysiological classification of cirrhosis. Hepatology, 51 (4), 1445-1449.

Giannini, E., Botta, F., Fasoli, A., Ceppa, P., Risso, D., Lantieri, P. B., Celle, G., Testa, R. (1999). Progressive liver functional impairment is associated with an increase in AST/ALT ratio. Dig. Dis. Sci., 44, 1249-1253.

Gines, P., Quintero, E., Arroyo, V., Teres, J., Bruguera, M., Rimola, A., Caballeria, J., Rodes, J., Rozman, C. (1987). Compensated cirrhosis: Natural history and prognostic factors. Hepatology, 7, 122-128.

Huwart, L., Sempoux, C., Vicaut, E., Salameh, N., Annet, L., Danse, E., Peeters, F., Beek, L. C., Rahier, J., Sinkus, R., Horsmans, Y., van Beers, B. E. (2008). Magnetic resonance elastography for the noninvasive staging of liver fibrosis. Gastroenterology, 135, 32-40.

Kelly, M. L., Riordan, S. M., Bopage, R., Lloyd, A. R., Post, J. J. (2018). Capacity of non-invasive hepatic fibrosis algorithms to replace transient elastography to exclude cirrhosis in people with hepatitis $\mathrm{C}$ virus infection: A multi-centre observational study. PLOS ONE, 13 (2), e0192763.

Kose, S., Ersan, G., Tatar, B., Adar, P., Sengel, B. E. (2015). Evaluation of percutaneous liver biopsy complications in patients with chronic viral hepatitis. Eurasian J. Med., 47,161-164.

Lieber, C. S., Weiss, D. G., Morgan, T. R., Paronetto, F. (2006). Aspartate aminotransferase to platelet ratio index in patients with alcoholic liver fibrosis. Amer. J. Gastroenterol., 101, 1500-1508.

Lurie, Y., Webb, M., Cytter-Kuint, R., Shteingart, S., Lederkremer, G. Z. (2015). Non-invasive diagnosis of liver fibrosis and cirrhosis. World $J$. Gastroenterol., 21, 11567-11583.

Machado, N. N., Jackson, T., Ladhani, H. A., Marks, J. M. (2017). Managing complications in endoscopic procedures: Bleeding from a biopsy site. $\mathrm{Mi}$ nerva Chir., 72, 36-43.

Mak, K. M., Chen, L. L., Lee, T.-F. (2013). Codistribution of collagen type IV and laminin in liver fibrosis of elderly cadavers: Immunohistochemical marker of perisinusoidal basement membrane formation. Anat. Rec., 296, 953-964.

Minuk, G. Y. (2003). Hepatic regeneration: If it ain't broke, don't fix it. Can. J. Gastroenterol., 17 (7), 418-424.

Orasan, O. H., Ciulei, G., Cozma, A., Sava, M., Dumitrascu, D. L. (2016). Hyaluronic acid as a biomarker of fibrosis in chronic liver diseases of different etiologies. Clujul. Med., 89 (1), 24-31.

Park, G. J., Lin, B. P., Ngu, M. C., Jones, D. B., Katelaris, P. H. (2000) Aspartate aminotransferase. Alanine aminotransferase ratio in chronic hepatitis C infection: Is it a useful predictor of cirrhosis? J. Gastroenterol. Hepatol., 15 (4), 386-390.

Park, S. Y., Kang, K. H., Park, J. H., Lee, J. H., Cho, C. M., Tak, W. Y., Kweon, Y. O., Kim, S. K., Choi, Y. H. (2004). Clinical efficacy of AST/ALT ratio and platelet counts as predictors of degree of fibrosis in HBV infected patients without clinically evident liver cirrhosis. Korean J. Gastroenterol., 43, 246-251.

Pinzani, M., Rombouts, K., Colagrande, S. (2005). Fibrosis in chronic liver diseases: Diagnosis and management. J. Hepatol., 42 (Suppl. 1), S22-S36.

Poynard, T, Bedossa, P. (1996). An algorithm for the grading of activity in chronic hepatitis C. The METAVIR Cooperative Study Group. Hepatology, 24, 289-293.

Pohl, A., Behling, C., Oliver, D., Kilani, M., Monson, P., Hassanein, T. (2001). Serum aminotransferase levels and platelet counts as predictors of degree of fibrosis in chronic hepatitis C virus infection. Amer. J. Gastroenterol., 96 (11), 3142-3146.

Regev, A., Berho, M., Jeffers, L. J., Milikowski, C., Molina, E. G., Pyrsopoulos, N. T., Feng, Z. Z., Reddy, K. R., Schiff, E. R. (2002). Sampling error and intraobserver variation in liver biopsy in patients with chronic HCV infection. Amer. J. Gastroenterol., 97 (10), 2614-2618.

Sande, J. A., Verjee, S., Vinayak, S., Amersi, F., Ghesani, M. (2017). Ultrasound shear wave elastography and liver fibrosis: A prospective multicenter study. World J. Hepatol., 9, 38-47. 
Shaheen, A. A., Myers, R. P. (2007). Diagnostic accuracy of the aspartate aminotransferase-to-platelet ratio index for the prediction of hepatitis C-related fibrosis: A systematic review. Hepatology, 46, 912-921.

Sheth, S. G., Flamm, S. L., Gordon, F. D., Chopra, S. (1998). AST/ALT ratio predicts Cirrhosis in patients with chronic hepatitis $\mathrm{C}$ virus infection. Amer. J. Gastroenterol., 93, 44-48.

Soresi, M., Lydia, G., Cervello, M., Licata, A., Montalto, G. (2014). Noninvasive tools for the diagnosis of liver cirrhosis. World J. Gatroenterol., 20 (48), 18131-18150.

Sterling, R. K., Lissen, E., Clumeck, N., Sola, R., Correa, M. C., Montaner, J., Sulkowski, M. S., Torriani, F. J., Dieterich, D. T., Thoms, D. L., Messinger, D., Nelson, M., APRICOT Clinical Investigators (2006). Development of a simple noninvasive index to predict significant fibrosis in patients with HIV/HCV coinfection. Hepatology, 43, 1317-1325.

Tchatalbachev, V. V., Kirkpatrick, D. L., Duff, D. J., Travis, M. D. (2015). Seeding of the rectus sheath with hepatocellular carcinoma after image guided percutaneous liver biopsy using coaxial biopsy needle system. $J$. Radiol. Case Rep., 9, 18-25.

Ustündag, Y., Bilezikēi, B., Boyaciošlu, S., Kayataž, M., Odemir, N. (2000). The utility of AST/ALT ratio as a noninvasive demonstration of the degree of liver fibrosis in chronic HCV patients on long-term haemodialysis. Nephrol. Dial Transplant, 15, 1716-1717.

Vallet-Pichard, A., Mallet, V., Nalpas, B., Verkarre, V., Nalpas, A., Dhalluin-Venier, V., Fontaine, P., Pol, S. (2007). FIB-4: An inexpensive and accurate marker of fibrosis in $\mathrm{HCV}$ infection. Comparison with liver biopsy and fibrotest. Hepatology, 46, 32-36.

Wai, C. T., Greenson, J. K., Fontana, R. J., Kalbfleisch, J. D., Marrero, J. A., Conjeevaram, H. S., Lok, A. S. (2003). A simple noninvasive index can predict both significant fibrosis and cirrhosis in patients with chronic hepatitis C. Hepatology, 38, 518-526.

Williams, A. L., Hoofnagle, J. H. (1998). Ratio of serum aspartate to alanine aminotransferase in chronic hepatitis. Relationship to cirrhosis. Gastroenterology, 95, 734-739.

Received 19 January 2020

Accepted in the final form 27 February 2020

\section{ROBEŽVĒRTĪBU NOTEIKŠANA NEINVAZĪVIEM AKNU TESTIEM, LAI VARĒTU AR AUGSTU JŪTĪBU DIAGNOSTICĒT AKNU CIROZI}

Aknu ciroze ir hronisku aknu slimību gala stadija. Pašreizējam zelta standartam tās diagnostikā — aknu biopsijai — ir pārāk daudz trūkumu, un aktīvi tiek meklētas jaunas alternatīvas. Lielu dalu no diagnostiskā arsenāla aiznem dažādu seroloğisko markieru kombinācijas jeb tā sauktās formulas. Tās tiek nepārtraukti pārbaudītas dažādos pētījumos, un tiek radītas jaunas. Mūsu retrospektīvajā pētījumā, kurā iekḷāvām 215 pacientus ar pierādītu dažādas etiolog̣ijas aknu cirozi, no slimības vēsturēm pārbaudījām piecu vairāk dokumentēto formulu jūtību un izvirzījām jaunus formulu robežpunktus aknu cirozes diagnostikā. Dati tika iegūti Rīgas Austrumu klīniskās slimnīcas arhīvā laikaposmā no 2012. līdz 2017. gadam un analizēti, izmantojot SPSS v.22.00 programmu. Mūsu pētījumā tika konstatēts, ka FIB-4 formula ar robežvērtību $<1.45$ ir ar 95\% jūtības spēju izslēgt nopietnu aknu fibrozi, neatkarīgi no cirozes etioloğijas. Nevienai no mūsu apskatītajām formulām nebija augsta jūtība alkohola izraisītas cirozes grupā. Lai diagnosticētu cirozi, ko izraisījis vīrushepatīts C, labāka izvēle būtu deRitis attiecība, kurai šajā grupā bija gandrīz 90\% jūtība. FIB-4 ar robežvērtību > 2.75 ir labākā izvēle, lai diagnosticētu kombinētu alkohola un vīrushepatīta $\mathrm{C}$ ǵenēzes cirozi; Bonacini ar 8+ punktiem un FIB-4 > 3.25 ir ar augstāko jūtību, lai diagnosticētu cirozi neatkarīgi no tās etioloǵijas. 